\title{
Faren ved å overdrive bruken av laboratorieprøver
}

\author{
Odyssevs kom seg til slutt trygt hjem til sin kone etter å ha vært utsatt for fristelser og farer på sin mangeårige \\ ferd tilbake fra krigen. For pasienter som blir fanget i laboratorielabyrinten, ender det ikke alltid så godt...
}

| 1960- og 70-årene skjedde det en stor økning i bruken av laboratorieprøver ved utredning av pasienter. Presisjonen og standardiseringen av analysene var ikke så gode som nå, og det var ikke sjelden store avvik i prøveresultatene. I tillegg kan det være store individuelle forskjeller mellom friske personer, dessuten kan laboratorieverdier variere over tid. For noen typer analyser er det kjent at verdiene kan variere betydelig med døgn og årstid. Det såkalte referanseområdet for normale personer var definert som $95 \%$ av alle måleverdier, slik at $5 \%$, eller $2,5 \%$ til hver side av grenseverdien, falt utenfor. Det medførte at én av 20 prøver ville ligge utenfor «normalområdet» selv om pasienten var frisk. Hvis så skjedde, var legen nødt til å ta en rekke nye prøver for å verifisere eller avkrefte om det var noe som feilte pasienten, og da kunne andre prøver vise et tilfeldig «unormalt» resultat. I verste fall kunne pasienten bli innlagt til utredning og «vandre»fra avdeling til avdeling fordi ingen torde ta ansvaret for at det ikke var noen sykdom. Dette fenomenet var kjent fra anglosaksisk litteratur under navnet the Ulysses syndrome lodyssevssyndromet), men hadde ikke vært beskrevet i Norge.

Jeg kunne ikke dy meg og skrev en spøkefull artikkel om emnet, der jeg viste til en rekke tilfeller hvor pasienter var blitt direkte skadelidende på grunn av ukritisk bruk av laboratorieprøver. En alvorlig artikkel ville virke som en krass anklage mot kollegene mine, og det ville jeg ikke. I stedet ble det en humoristisk fremstilling, så fikk hver og en ta det til seg dersom de følte seg truffet.

Artikkelen ble utgitt i Nordisk Medicin, som ble sirkulert til alle leger i Norden, og den slo ned som en bombe. I etterkant ble det en hissig diskusjon i bladet med tallrike innlegg om bruk og misbruk av laboratorieprøver og hvordan falskt positive resultater kunne forhindres. I årene siden er de diagnostiske hjelpemidlene blitt radikalt forbedret - men hvem vet om ikke den gode Odyssevs fortsatt lurer i buskene!

\section{Ole Didrik Lærum}

ole.laerum@gades.uib.no

Ole Didrik Lærum (f. 1940) er professor (adj.) ved Københavns Universitet og professor emeritus i patologi ved Gades institutt, Universitetet i Bergen.

\section{Ulysses-syndromet - helseproblemer hos pasienter med «non-disease»}

Ole Didrik Lærum Ulysses-syndromet - helseproblemer hos pasienter med «non-disease». Nord Med 1976; $91: 205$ - 7.

Det er ikke bare medisinske lærebøker som er vanskelige. Ofte er den virkeligheten de forsøker å beskrive enda vanskeligere. Spesielt problematisk er det når viktige syndromer ikke engang blir omtalt i bøkene.

De forskjellige sykdommer har en tendens til å oppføre seg tildels uforskammet uavhengig av lærebøkene. Tross vår stadige innføring av nye syndromer og sykdomsenheter, klarer vi ikke å holde tritt med virkelighetens foranderlighet. Spesielt vanskelig er det når det dreier seg om såkalte antisykdommer, det vil si syndromer hvis oppståen har sammenheng med den moderne medisi- nens ulykksalige tendens til å lete etter sykdommer der de ikke finnes, noe som igjen kan være sykdomsfremkallende, eller helst motsatt.

Her kommer Ulysses-syndromet inn som en viktig og lite påaktet enhet (3). I Homers Odysseen brukte sagnhelten Odyssevs (engelsk: Ulysses) over 20 år på å komme seg hjem fra beleiringen av Troja, enda distansen var ganske kort. Undervegs kom han ut for all slags hendelser og farer som brakte ham inn på nesten endeløs omveger, før han tilslutt vendte hjem til sin ventende Penelope og til hunden som døde av glede over å se ham.

\section{Et resultat av den økende prøvetaking}

Ulysses-syndromet er et resultat av den økende prøvetaking i moderne medisin. Hver laboratorieprøve har et normalområde som gjerne defineres som 95 prosent av alle verdier, fordelt rundt en bestemt middelverdi. Det medfører at per definisjon vil 5 prosent av en normalbefolkning risikere å vise «unormale» verdier uten at det feiler dem noe (8). Hvis det gjøres 20 laboratorieprøver på hver frisk person, vil 66 prosent av dem oppleve å få ett eller flere unormale prøveresultat. Hos en slik person vil dette resultatet av legen bli oppfattet som patologisk, og det fører til nye undersøkelser. 